\title{
The Hermeneutic Tradition from Schleiermacher to Kierkegaard
}

So far we have considered the general forms taken by the commerce
between author, reader, and text, but not the figures who make romantic hermeneutics different from its precursors. The history of hermeneutics from Schleiermacher to Dilthey is the history of an expansion of the field of study to include not only biblical and secular texts but all human phenomena-from texts to gestures and actions-that use sensory signs to convey an inner spiritual reality. ${ }^{1}$ This expansion has consequences for modern semiotics that will not be pursued here, for the romantic period initiates an awareness of empirical 'realities' as textual phenomena. But it is the increasing sense that signs may not adequately convey interiority that will be the concern of this chapter. To begin with, this inadequacy is the product of a temporal distance between author and reader that we can overcome through a process of historical reconstruction or re-experiencing (Nacherleben). ${ }^{2}$ More and more, however, the inner meaning of a text is deferred to the future and becomes something to be projected rather than recovered by the reader. This chapter traces the movement from a positive hermeneutics that deepens or completes the text to a negative hermeneutics that resists it. It follows this movement through the work of Schleiermacher and others to that of Hegel, which stands ambiguously on the borderline between the two varieties of hermeneutics, and finally to the work of

'Wilhelm Dilthey, "The Understanding of Other Persons and Their Expressions of Life," Descriptive Psychology and Historical Understanding, trans. R. M. Zaner and K. L. Heiges (The Hague: Martinus Nijhoff, 1977), pp. 123-24.

${ }^{2}$ The term is Dilthey's but it can apply equally well to Schleiermacher (ibid., p. 132). 
Schelling and (more self-critically) Kierkegaard. ${ }^{3}$ In the process it also discloses the increasingly problematical status of the supplement of reading. For the growing estrangement of the 'true' meaning from what appears in the written text or the language of events comes perilously close to deconstructing the transcendental signified. If this meaning cannot be represented, we must ask, is there any guarantee that it exists? Kierkegaard's Concept of Irony, as a form of what he later calls "doubly reflected communication" ( $P V$, p. $\left.1_{5}^{6}\right)$, simultaneously manifests and reflects on its own desire for authoritative meaning. It therefore marks a fitting close to one chapter in the history of hermeneutics and an appropriate transition to another. This further chapter, which is simultaneous with rather than subsequent to the first, explores the continued importance of reading as a way of renewing writing. But it replaces the work as origin with the work as originating productivity, and thus radically reconceives what is involved in the supplement of reading.

\section{Positive Hermeneutics: Schleiermacher and His Circle}

The separation of form from meaning seems to begin with Schleiermacher's sense of the need for a 'psychological' as well as 'grammatical' or literal reading of texts. This need is first articulated only in the 1819 Compendium $^{4}$ and distinguishes him from his predecessor J. A. Ernesti,

${ }^{3}$ I do not consider the hermeneutics of Dilthey in detail because chronologically as well as intellectually he falls outside the range of this study. Dilthey marks the return of hermeneutics to a positivist concern with textual expressions as interpreted through a structural hermeneutics. This chapter traces an increasingly metaphysical tendency in romantic hermeneutics. The next chapter outlines an emphasis on the linguisticality of understanding, which is, however, phenomenological rather than structuralist.

${ }^{4}$ The development and textual history of Schleiermacher's hermeneutics are complicated. For a long time the only available edition of the Hermeneutics was that of his student Friedrich Lücke, based on the manuscript now referred to as the Compendium of 1819 , supplemented by lecture notes taken in $1828-29$ and $1832-33$. In 1959 Heinz Kimmerle brought out an edition of the various handwritten manuscripts of the hermeneutics, beginning with the aphorisms of 1805 and including the first draft of $1809-1810$, the Compendium (the only substantial manuscript), the 1829 "Academy Addresses," and the less complete material written between 1826 and 1833 (cited in text and notes by the abbreviation $H$ ). The effect of Kimmerle's edition is to make us aware of shifts and tensions in Schleiermacher's thinking, which are not necessarily confined to those outlined by Kimmerle himself. Kimmerle argues that the early Schleiermacher is much more committed to the identity of thought and language than the later Schleiermacher, who tends toward a psychologism that posits thought as something ideal and separable from its verbal expression. The 1819 Compendium is a transitional work that begins this move, but in which the linguistic emphasis is still evident in the decision to retain the label of 'technical' interpretation for the detailed account of the second level of reading, instead of the term 'psychological' interpretation introduced for the first time in the general introduction. Thus it is not until the "Academy Addresses" of 1829 that "the second part of the theory of understanding developed in a way that corresponds to the introduction of 1819 " $(H, p .39)$. Behind 
who makes other forms of reading mere aids to grammatical interpretation. Briefly, grammatical study is concerned with the meanings of and interconnections between individual words $(H$, p. 147), but not with form or structure in an aesthetic sense. Psychological reading, on the other hand, understands the text from within and thus breaks the hermeneutic circle. It seeks an "identification with the author" $(O, p .10)$ through a return to the point of origin of a text (Anfangspunkt), a point that simultaneously reveals the arche and telos of the discourse $(H K, \mathrm{p}$. 154), by way of a circular understanding that comprehends the unity of the work through its parts and understands the significance of each part

Kimmerle's project is a desire to defend Schleiermacher against the criticism of Gadamer, by making available his early theories on hermeneutics. The view that Schleiermacher neglected language, as Kimmerle points out, comes from Dilthey's account of him in "The Rise of Hermeneutics" (New Literary History 3 [1971-72]), and Dilthey in turn relied on Lücke's edition, which draws only on Schleiermacher's later work.

My own treatment of Schleiermacher follows two divergent lines, one of them revisionary, but in a diff erent way from Kimmerle's treatment. In the present chapter, I discuss the Schleiermacher popularized by Dilthey and criticized in our own time by Gadamer and Kimmerle himself, who favors the early Schleiermacher. There is obvious evidence in the later hermeneutics for a psychologistic reading of Schleiermacher. However, I argue in the next chapter that the later Schleiermacher is actually much more complex than either Dilthey or Kimmerle allow, and that he uses the 'psychological' in a much more explicitly problematic way than either Hegel or Schelling. If the early Schleiermacher is something of a structuralist in his use of grammatical and linguistic models to illuminate 'technical' interpretation and in his assumption that the technical and the grammatical are related like parole and langue, the later Schleiermacher is romantic in his concern with the psychological but incipiently deconstructive in his treatment of 'psychology.' Moreover, he remains committed to the interconnection between thought and language, but the 'linguisticality of understanding' now implies a language that is different from itself-hence my reference to the 'interconnection' rather than the 'identity' of thought and language.

For obvious reasons I have used the Lücke version of the hermeneutics as well as the Compendium. As Kimmerle admits, his own edition does not make Lücke's superfluous, because the latter draws on lecture notes by Schleiermacher's students $(H$, p. 23o), which are considerably fuller than Schleiermacher's notes of 1832-33 published by Kimmerle, yet are in no way inconsistent with these notes. My discussion in these chapters therefore draws on the following texts: $(A)$ The translation by Jan Wocjik and Roland Haas of "The Hermeneutics: The Outline of the 1819 Lectures", New Literary History 10 (1978): 1-16. I have preferred this abbreviated translation (cited in text and notes as $\mathrm{O}$ ) to the English translation of the Kimmerle edition $(H)$ because it seems more faithful at certain points. Where the Wojcik translation is incomplete, I have also drawn on the "Compendium of 1819 " (MS 3 ) as printed in the English translation of the Kimmerle edition. This consists of an introduction, a first part on 'grammatical' interpretation, and a brief second part on 'technical' interpretation. $(B)$ The "Draft for the Presentation of the Second Part" (MS 3 ', 1826-27) and "The Separate Exposition of the Second Part" (MS 4, 1826-27), both in $H$. $(C)$ "The Two Academy Addresses of 1829 " (MS 5 ) in $H$. (D) "The Marginal Notes of 1832-33" reprinted in $H$, and the Lücke edition (cited in text and notes as $H K$ ). The latter is valuable not only because it provides a fuller account of 'psychological interpretation' than is available from the marginal notes, but also because it indicates that in his final lectures Schleiermacher devoted an autonomous (and apparently lengthy) section to psychological as distinct from technical interpretation. 
in the light of the whole. A third level of reading often discussed in biblical and legal hermeneutics, the applicative, ${ }^{5}$ is also tacitly present in Schleiermacher's theory. For psychological reading also requires readers to engage in a more conservative version of what Paul Ricoeur calls Aneignung, making the text our own, in order to grasp it as part of our lives and not just as a historical document. ${ }^{6}$ Because the concept of application locates the significance of the text partly in its effect on the reader (Wirkung), it raises a problem implicit in psychological reading as well: namely, that meaning is not something contained in the text, but also something that remains suspended until it is confirmed through understanding and enactment.

Whether the need to go beyond grammatical reading of the text in order to actualize it denies the presence in it of incarnate meaning is a question that has troubled interpreters of Schleiermacher. Two antecedent traditions in hermeneutics-the theological and philological-are worth mentioning, because they indicate that multileveled reading does not have to result in the severance of the inner from the outer. Already in Francke's Praelectiones and Rambach's Institutions we find distinctions between the grammatical, literal or real, and the spiritual senses of a text. The similar vocabulary suggests that Schleiermacher's hermeneutics may have begun as a secularized version of medieval exegesis, replacing the anagogic by the psychological level, and translating the moral or tropological level as applicative reading. The fourfold method, too, raises problems of the separation of meaning from depiction, which Christian theorists argue around. Summing up the tradition, Erich Auerbach distinguishes allegory, which empties out the sensory level by making it a mere sign, from figural writing and interpretation, which permit both "poles-the figure and its fulfilment-to retain the characteristics of concrete historical reality." 7 Psychological reading may well have been conceived on the model of figural interpretation, as informing the grammatical rather than replacing it. Similarly, philologists before Schleiermacher had introduced the notion of multilayered reading without moving in a phenomenological direction. Spinoza, for instance, distinguishes grammatical, structural, and historical reading, which focus respectively on the meaning of words, the coherence of the text,

${ }^{5}$ David Hoy, The Critical Circle: Literature, History, and Philosophical Hermeneutics (Berkeley: University of California Press, 1982), p. 53.

${ }^{6}$ Hermeneutics and the Human Sciences, ed. and trans. John B. Thompson (New York: Cambridge University Press, 1982), pp. 182-93.

${ }^{7}$ Mimesis: The Representation of Reality in Western Literature (Princeton, N.J.: Princeton University Press, 1953), pp. 195-96. On the difference between allegory and typology see also Leonhard Goppelt, Typos: The Typological Interpretation of the Old Testament in the New, trans. Donald H. Madvig (Grand Rapids, Mich.: Eerdmans, 1982), pp. 7, 13. 
and the historical context, including knowledge of author and reader. ${ }^{8}$ F. A. Wolf posits three complementary methods of reading: the grammatical, the historical, and the philosophic ${ }^{9}$ (or at other times the rhetorical). ${ }^{10}$ Grammatical interpretation is concerned with the signifier (though regarded as referentially stable), historical interpretation is concerned with the text's contexts, and philosophic interpretation counteracts the centrifugal tendencies of history and biography by returning to what the text says. Schleiermacher was critical of Friedrich Ast, who was much more romantic in the use he made of multilayered reading, envisioning a spiritual (geistig) rather than a philosophic reading at the third level. As the term geistig with its premonitions of Hegel indicates, such a reading is concerned with the spirit of the work as part of the spirit of the age and the world-view of its author. For the early Schleiermacher such encyclopedic notions take hermeneutics in a metaphysical and idealist direction. ${ }^{11}$

But despite these qualifications, which apply largely to his early work, it is not possible to put Schleiermacher on the conservative side of the great divide between philology and phenomenology. For on a theoretical level he increasingly develops in the direction of Ast. His replacement of Wolf's 'philosophic' reading with psychological reading marks a shift away from pure philology, though in an unorthodox way he always remains a philologist. Moreover, in borrowing from Ast the concept of the hermeneutic circle, Schleiermacher commits himself to precisely the approach he sometimes condemns: to reading the work as a totality and thus to a reliance on intuition foreign to philology. The analogy between psychological and figural reading similarly masks a problem. For it is arguable that figural reading cannot really escape the privileging of a 'deeper' meaning, and that the opposition between figure and allegory is tenuous. Indeed, Auerbach concedes that Christianity may be shadowed by an "antagonism between sensory appearance and meaning" and that the figural may be a compensatory attempt to overcome tensions between the letter and the spirit, ${ }^{12}$ recognized by the interpretive tradition of Augustine, Origen, and Philo. ${ }^{13}$ In terms of his practical criticism, it is

${ }^{8}$ Benedict de Spinoza, A Theological Political Treatise and A Political Treatise, trans. R. H. M. Elwes (New York: Dover, 1951), pp. 101-104. The terms 'grammatical,' 'structural,' and 'historical' are those of Tzvetan Todorov, Symbolism and Interpretation, trans. Catherine Porter (Ithaca, N.Y.: Cornell University Press, 1982), pp. 140-42.

${ }^{9}$ Richard Palmer, Hermeneutics (Evanston, Ill.: Northwestern University Press, 1969), p. 82.

${ }^{10}$ Todorov, Symbolism and Interpretation, p. 154.

${ }^{1}$ Palmer, Hermeneutics, p. 85 .

${ }^{12}$ Mimesis, pp. 49, 75 .

${ }^{13}$ Origen, too, has a theory of multilayered reading, consisting of the somatic (grammatical-historical), the psychic (moral), and the pneumatic (allegorical-mystical). But his theory is formulated in terms of an opposition between the body and the spirit which devalues the 
not always easy to say where Schleiermacher stands. In his Life of Jesus he appears to favor texts that make the spiritual present at the literal level, and only reluctantly devises a hermeneutic for texts that fail to do so. But in his Introductions to the Dialogues of Plato, external and inward readings of texts are opposed in terms of a romantic vocabulary that privileges the inner as closer to life and the outer as more mechanical. It may be that as a practical critic Schleiermacher found it difficult to construct a general hermeneutic that would apply to all texts, and that his interest for the future lies precisely in the fact that he is not theoretically monolithic.

For the purposes of this chapter, however, Schleiermacher's position in romantic hermeneutics will be measured not so much in terms of what he first 'intended' as in terms of his influence, and in terms of those shifts in nineteenth-century thought for which he created an opening. It is generally felt that his work consolidated a movement away from the rules of exegesis to the theory of understanding, even if the latter was still bound up for him with what Peter Szondi calls the earlier "material hermeneutics." 14 Arguments for Schleiermacher's conservatism depend on a genetic fallacy that allows the interpretation of his later work to be governed by his earliest statements on hermeneutics. But it seems clear that he moved away from a hermeneutics centered on 'grammar,' even if certain tensions remain in his writing. And since Schleiermacher himself suggests that interpretation must be 'divinatory' as well as 'historical,' it seems appropriate to read him in the light of his own principles. The historical method examines the text as a finished product, whereas the divinatory method grasps it as a moment in a process and considers how a discourse that is produced by a certain line of thought in turn reacts upon those thoughts, so as to require a reader who will understand "better than its creator" the potential within it $(\mathrm{O}, \mathrm{p}$. 9). From a divinatory perspective Schleiermacher prepared the ground for a hermeneutics that looks for something more than what is actually given in the text, and in his analysis of Plato and the gospels he focused on a disintegration of coherence at the grammatical or literal level that made this more inward reading necessary. Thus he spoke to a specifically romantic dilemma, in a way that Ernesti and Wolf could not. The structural, stylistic, and ideological problems that he saw in classical and biblical texts were

former. See Peter Szondi, "Introduction to Literary Hermeneutics," New Literary History 10 (1978): 24-25. See also Karlfried Froehlich, “'Always to Keep the Literal Sense in Holy Scripture Means to Kill One's Soul': The State of Biblical Hermeneutics at the Beginning of the Fifteenth Century," Literary Uses of Typology from the Later Middle Ages to the Present, ed. Earl Miner (Princeton, N.J.: Princeton University Press, 1977), p. 22. On Philo's relation to this tradition see Goppelt, Typos, pp. $4^{2-53}$.

14"Introduction to Literary Hermeneutics," p. 19. 
also those that existed in romantic texts, and the recourse to interpretation as a way of making the text present to itself was typical of an age that saw self-consciousness as a way to heal itself.

What is less clear is whether psychological reading recovers the identity of the text, and whether in the end romantic theorists see such identity as desirable. The counterplot of romantic hermeneutics and phenomenology, however-their disclosure of how the recourse to reading and speech disseminates meaning-is something that will be considered in the next chapter. Paradoxically, a principal figure in this counterplot is Schleiermacher himself. For the divinatory reading of his work that developments in contemporary theory permit is very different from the one attempted in this chapter: from the reading actually assumed by Dilthey, who considered only the later version of the hermeneutics compiled by Friedrich Lücke and used it to link 'Schleiermacher' to a psychologism Dilthey himself was to leave behind.

'Schleiermacher's' statements on hermeneutics took form between 1805 and 1833 , and have been read as moving increasingly toward a psychologism that separates thought from language. The 1819 Compendium, the first extensive outline of the hermeneutics, occupies a transitional position in this development. Already Schleiermacher distinguishes between discourse (Reden) and text (Schrift) and postulates a "difference" between them caused by the absence of the living voice $(\mathrm{O}$, p. 1). The aim of hermeneutics is to move behind the text to this living discourse $(\mathrm{O}, \mathrm{p} .10)$. But it would be wrong to assume that this discourse is something unavailable through language or even writing. For at this stage, though the term 'psychological' occurs, it is used synonymously with 'technical,' which has to do with the author's subjectivity as it finds expression in aesthetic forms. In a sense the technical is an extension of the grammatical, ${ }^{15}$ concerned with form rather than syntax, with the unique style that informs an author's connecting of words, but also with those larger organizations of parts into a whole that yield "the unity of the work" or the "theme" (O, pp. 12-13). The technical reading does not seem to create a fissure between the psychological and the grammatical, but rather acts as a bridge between 'discourse' and text. Indeed, the following description of technical reading makes clear the formalist assumptions that counterbalance the phenomenological distinction of discourse from text: "The ultimate goal of the psychological [technical] exposition is nothing other than to perceive the consequences of the beginning; that is to say, to consider the work as it is formed by its parts,

${ }^{15}$ Gadamer also notes, in reference to Schleiermacher's later tripartite division, that the technical is analogous to the grammatical: "The Problem of Language in Schleiermacher's Hermeneutic," in Schleiermacher as Contemporary, ed. Robert W. Funk (New York: Herder and Herder, 1970), p. 82. 
and to perceive every part in light of the work's overall subject as its motivation; this is also to say that the form is seen to be shaped by the subject matter" (O, p. 13).

On the other hand, it would be equally wrong to argue that Schleiermacher moves decisively against the concept of a meaning that can be intimated by but not embodied in the text. The Compendium also contains an important distinction between the historical and the divinatory or prophetic methods, which is used to intersect the initial division of reading into the grammatical (objective) and the psychological (subjective). Thus Schleiermacher introduces four categories: the objectivehistorical, the objective-divinatory, the subjective-historical, and the subjective-divinatory. Whereas the historical is concerned with the text as achieved form, the proto-Hegelian concept of the divinatory is concerned with the text as part of an ongoing process that requires an imaginative leap on the part of the reader to discern its direction. Objective-historical reconstruction concerns itself with the text as a product of the existing system of language, including genre as well as grammar, and objective-divinatory reconstruction assesses how "the discourse itself developed the language" (O, p. 9). Subjective-historical reconstruction is similar to what Schleiermacher later defines as 'technical' reading: it considers the text as an objective correlative of the author's mind. But subjective-divinatory reading seems to go beyond the merely technical to consider what has not yet found expression in the text, namely, the process initiated by but not completed in its writing $(O, p .9)$.

Between 1826 and 1833 Schleiermacher considerably expanded what he had to say about psychological reading, not, as is sometimes supposed, in order to replace the term 'technical' with 'psychological,' but in order to create two autonomous subdivisions within the psychological: the technical, and the psychological proper. These two readings strain in opposite directions, toward and away from attention to what he calls the "text" (Schrift), and it is by no means clear that they can be made concentric to each other. Already in the Compendium, Schleiermacher allows that classical and romantic works require different methods of reading $\left(\mathrm{O}, \mathrm{pp} .4^{-5}\right)$, and so it seems logical that some works might yield more to psychological than to technical reading, and might not be readable as works that have fully actualized their meaning. In the final lectures the long section on psychological reading that follows the briefer account of technical reading repeated from 1819 begins by distinguishing "the indefinite, flowing thought-process" from the "finished thought-complex" ( $H K$, pp. 148-49). It is the latter that is the object of a technical analysis concerned with "a definite thought and will to representation" and with "the objective realisation" of this creative resolve in the text $(H K$, p. 154). Technical analysis, in other words, focuses on what 
Schleiermacher calls "meditation and composition," the linear shaping of a creative intention into a text. But psychological reading is concerned with the "rise of thought out of the entirety of the life moments of the individual" $(H K$, p. 152), with the intuitions in which thought has its inception, and therefore not simply with the thought expressed but also with underlying and collateral thoughts (Grundgedanken and Nebengedanken).

As in the 1819 Compendium, where he insists that grammatical and technical reading are complementary, Schleiermacher here emphasizes the interdependence of the technical and the psychological. In order to grasp the discourse as a whole, it is necessary to understand it from its point of inception and thus to read psychologically; but in returning to the conception, we also see it taking form and thus engage in technical reading. That reading involves a back-and-forth movement between understanding the thought process and its formalized expression is undoubtedly true. Yet it does not follow that there is a symmetrical relationship between conception and expression. For there seems to be more behind the text than is articulated in it, and what there is behind it is also more inchoate. To the extent that Schleiermacher is committed to grasping the life moments of the author as a unity, the psychological reading has to take a divinatory form by discerning a direction in the indefinite thought process-something that the reader would not have to do if the finished text already fully articulated that direction. In other words, the reader must try to understand "the discourse just as well and even better than its creator" $(\mathrm{O}, \mathrm{p} .9)$.

Hans Frei emphasizes that Schleiermacher does not intend to make words "a secondary expression of a putatively more real internality." 16 But he also points to the difficulty Schleiermacher has in maintaining the unity of the psychological and the grammatical-a difficulty that only increases after him. To recognize how far his theoretical work ${ }^{17}$ marks a turning point in the history of hermeneutics, it is worth considering two other theorists more strictly philological than he: his precursor J. A. Ernesti, and August Boeckh, who wrote somewhat later. Ernesti's Institutio Interpretis ( 1761$)$ occupies a pivotal and complex position. From a later perspective he seems a fundamentalist, concerned with the literal meaning of texts and committed both to the clarity and unity of such texts. On the other hand, he is also a product of Enlighten-

${ }^{16}$ The Eclipse of Biblical Narrative: A Study in Eighteenth and Nineteenth Century Hermeneutics (New Haven, Conn.: Yale University Press, 1974), p. 309.

${ }^{17}$ I use the term 'theoretical work' because I suggest in the next chapter that Schleiermacher's commentaries on Plato and Luke are strongly philological and use philology not to fix meaning but as part of a dialectical process designed to make the reader see through precisely this attempt. 
ment rationalism and of its reaction against pietist hermeneutics, which sought to place the meaning of the text outside it, in the coincidence of the interpreter's reading with the voice of the holy spirit. Thus, on the one hand, Ernesti seems conservative in his attitude toward interpretation as the fixing of meaning and argues that the Bible is incapable of contradiction: if "any contradiction should appear to exist, a suitable method of reconciliation is to be investigated." 18 On the other hand, he insists that the unified meaning of the biblical text is not to be sought outside it: "when different reasons for the meaning of a word oppose each other," greater weight ought to be given to "the accurate interpretation of words" than to "the illustration of previously formed opinions." 19 Following the Enlightenment view that there is a direct but customary correspondence between words and things, Ernesti argues that there are three criteria for the interpretation of texts: the meaning of words, the historical context governing their usage, and the author's intention. ${ }^{20}$ But none of these criteria lead beyond the grammatical level: as Hans Frei observes, "Ernesti does not think of the author's intention as a privileged realm beyond his words... . The words constitute the intention." 21

In contrast to the later Schleiermacher, Ernesti thus sees the grammatical level as primary. Though he uses what Ast and Wolf call historical reading, the purpose of context (whether biographical or cultural) is to redirect our attention to the individual words rather than to supply what is implied between the lines or explain what the words cannot fully articulate. 'Psychological reading' is not a term that Ernesti uses, and he has little patience with allegorical reading, which is of ten fanciful in constructing a meaning beyond the literal. To the mystification of allegorizing he opposes the scientific procedures of philological understanding, which deals only with what is there. ${ }^{22}$

It is arguable that Ernesti's privileging of the grammatical is hard to sustain. For one thing, he relies on the atomistic theory of language common at the time, which focuses on single words as positive terms and thus brackets the erosion of referential stability that would arise if meaning were considered at the level of larger units like the proposition or the narrative episode. As a result he does not have to move beyond the grammatical level to recover that self-identical meaning that seems the goal of traditional hermeneutics. It is also arguable that he does not

\footnotetext{
18 Principles of Biblical Interpretation, trans. Charles H. Terrot, 2 vols. (Edinburgh: Thomas Clark, 1843), I, 38 .

19Ibid., I, 37; II, 193.

20Ibid., I, 28, 63 .

${ }^{21}$ Eclipse of Biblical Narrative, p. $25^{2}$.

${ }^{22}$ Ernesti, Biblical Interpretation, I, 25; II, $189,192$.
} 
even succeed in locating meaning at the grammatical level. For as soon as one recognizes that words are governed by custom, it is necessary to refer to contexts beyond the words themselves; nor are such contexts always sufficient, as Ernesti himself concedes. ${ }^{23}$ But in terms of his aesthetic and hermeneutic norms, the search for a meaning that is not grammatically actualized is illegitimate, an embarrassment when it must occur.

To turn to Boeckh is to recognize the difference made by Schleiermacher's hermeneutics. Boeckh, who studied with Schleiermacher but was also influenced by Wolf, is also dedicatedly philological. But philology for him is not the study of words, but rather "the understanding of what has been produced by the human spirit." It is part of Boeckh's concept of the encyclopedia, which involves a global version of the hermeneutic circle in which particular areas of knowledge are to be understood only in relation to the entirety of human knowledge. ${ }^{24}$ Between Ernesti and Boeckh philology itself, once synonymous with a solidity that could not be accused of idealism, has moved from the grammatical level to what Ast called the geistige level. Similarly, at first glance Boeckh's various kinds of reading seem designed to minimize the psychological element, and terms like 'divinatory' and 'prophetic' are notably absent from his writing. He distinguishes two forms of objective understanding, the grammatical and the historical as in Wolf, and two forms of subjective understanding, the generic and the individual, the latter being rather like technical interpretation. This fourfold scheme seems designed to exclude anything beyond the words and form of a text. But it is not just that Boeckh is more sensitive than Ernesti to the destabilizing forces within grammar, nor even that he is more inclined to defer the act of understanding to the historical or generic level. He recognizes that the sufficiency of the grammatical level varies markedly in texts and diminishes considerably in some. ${ }^{25}$ Moreover, he envisions a situation in which the supplement of reading becomes an internal constituent of texts: a situation in which "the speaker or writer presupposes, consciously or unconsciously, that the people to whom he is addressing himself will not only understand his words grammatically, but will in connection with them think of more than they actually say." 26 In the end, despite his philological bias, he comes very close to Schleiermacher in feeling that the hermeneutic circle is not broken in an objective way, but through the construction of hypotheses about intention that depend

${ }^{23}$ Ibid., I, $178-79$.

${ }^{24}$ August Boeckh, On Interpretation and Criticism, trans. and ed. John Paul Pritchard (Norman: University of Oklahoma Press, 1968), pp. 31-33.

${ }^{25}$ Ibid., pp. 78, 53. Cf. also Schleiermacher (O, p. 5).

${ }^{26}$ Boeckh, On Interpretation, p. 77. 
on "intuition" and on a special affinity between reader and author. ${ }^{27}$ Most importantly, he recognizes the slipperiness of such interpretations. The attempt to ground interpretation through an appeal to historical facts is itself dependent on an act of interpretation to constitute those 'facts' as facts. The attempt to stabilize a text through "individual" interpretation of an author's lexicon is similarly problematic, because the assumption that "the subjective essence of the speaker mirrors itself in his language" encounters the obstacle of deciphering persona and narrative voice. ${ }^{28}$

As we consider the development of hermeneutics in the nineteenth century, it is clear that it changes from being an exegetical to a phenomenological method. But another development is also worth remarking: namely, the expansion of hermeneutics to the understanding of signs generally. Such a development does not have to lead in a metaphysical direction, but until Dilthey applies hermeneutic principles to the human and social sciences at the turn of the century, the main new trend is in fact the expansion of textual hermeneutics into a hermeneutics of being. This development has two consequences. The increasingly metaphysical orientation of hermeneutics intensifies the commitment to understanding as the finding of a transcendental signified, a ground outside the play of language. We have already seen this tendency in Schleiermacher. But inasmuch as his attitude to metaphysics is ambivalent, his notions of origin and ground will also emerge as more unstable than I have suggested. Second, with the broadening of literary into ontological hermeneutics, the rules of philology become less important, and psychological reading moves closer to what the term implies for a modern audience. This is not to say that the philological tradition disappears (Boeckh being an example to the contrary), but simply that ontological hermeneutics weakens the role played by "evidence" in interpretation, because being cannot very well be approached in terms of anything factual such as the literary or historical context. The notion of historical reading - an autonomous category in Ast and an autonomous mode of both the grammatical and psychological categories in Schleiermacher-largely disappears, leaving psychological reading to develop in a more intuitionist direction. The deemphasis on evidence can only augment the tendency for reading to become the reading of consciousness rather than of texts, and for poets to assume such a reading. As usual, Schleiermacher stands somewhere in the middle of this development, and it may be useful to compare him with another member of the Jena circle, Schelling, in order to see what happens 
to a hermeneutics of texts when it is rewritten as a hermeneutics of being.

Schleiermacher himself does not strictly adhere to his own restriction of hermeneutics to the study of written documents, since both his life of Jesus and his essay on Socrates deal with figures who are known only through the writings of others. Nevertheless, he himself does not take hermeneutics in an ontological direction. But the introduction to Schelling's Ages of the World, concerned as it is with the interpretation of being in its various stages of development, makes use of concepts with clear parallels in traditional hermeneutics to do precisely that. Whether the parallels represent the influence of Schleiermacher is not something that will be explored here, since the Ages was written between Schleiermacher's early and later courses of lectures, and since much that is in those lectures is not unique to him. Appended to one of the cornerstones of Schelling's later philosophy, the introduction seems a development of the earlier and more affirmative philosophy of identity-hence; the appropriateness of considering it here and not in conjunction with the later work. By the philosophy of identity we must understand not only the identity of self and other, but also the resulting achievement of identity with oneself. By extension we must also understand by the term the identity of author and interpreter, and the consequent grasping of the identity of the text or of the object being studied. Schelling is not so naive as to believe that this can be achieved $(A W$, p. 88$)$, but it remains a goal which we can and should approximate. He suggests that understanding, as it pertains to the interpretation of being, involves a dialectic between two voices within the interpreter: an inward self connected to the origin of things, and a lower and more self-conscious ego. The higher self is the ground of all truth but is ignorant of what it knows and needs the lower self in order to "make distinguishable, express, interpret" what otherwise remains inchoate $(A W$, p. 85$)$. Through the lower self, then, the higher is able to "view itself, represent and become intelligible to itself" ( $A W$, p. 85$)$.

In this manner Schelling takes a principle fundamental to his and Hegel's dialectics-namely, that the subject must become estranged from itself and become an object to itself before it can return to itselfand uses it to explain why vision must go through the detour of signs and their interpretation, why presence must be re-presented in order to become self-present. For our purposes, however, it is enough to note that the higher self is associated with immediate vision, where the lower self proceeds "piece by piece in a fragmentary way, with divisions and gradations" ( $A W$, p. 88$)$. The lower mode of understanding, in other words, corresponds to grammatical reading, where the higher parallels the psychological reading necessary to break the hermeneutic circle. 
Like Schleiermacher, Schelling claims not to argue for a hermeneutics of the ineffable and believes that the psychological and grammatical approaches are mutually necessary $(A W, \mathrm{pp} .87-89)$. Yet the hierarchy of lower and higher indicates where his emphases lie. As significantly, visionary understanding occurs not through the reading of outward signs or historical evidence, but rather through the awakening of an "archetype ... [that] slumbers in the soul like an obscured and forgotten, even if not completely obliterated, image" $(A W$, p. 85$)$. Part of the function of the lower principle is to raise to the level of consciousness representations that lie in the soul as pure forms without material content $(A W, \mathrm{p}$. $84 \mathrm{n}$ ). On one level, Schelling's account is more satisfactory as a description of how divination occurs than that of Schleiermacher. For the 1819 Compendium offers no explanation of divination, and the later definition of it as the recovery of secondary trains of thought is too linguistic to express that particular term. At the same time Schelling's more precise awareness of divination and of the psychological as the "unconscious" crosses a new threshold in romantic hermeneutics. With this development goes a return to a hermeneutics of faith, though not in the conservative way practiced by pietist hermeneutics. ${ }^{29}$ In different ways the theorists to be considered have recourse to a form of imaginative faith to supply what is not empirically given, Hegel by default and the later Schelling by design. ${ }^{30}$ With this recourse to faith comes a further separation of consciousness from its textual appearances, at least on the level of desire.

\section{Hegel and the Hermeneutics of History}

With Hegel we enter a new stage in the history of hermeneutics, namely, the expansion of a literary hermeneutics into a general hermeneutics concerned with all products of the human spirit. Paradoxically, this expansion has two different but intertwined effects. It makes hermeneutics more metaphysical in its claims, as interpretation claims to get at Truth and not just at the truth of a text. But it also makes metaphysics for the first time the subject of textual analysis. As we shall see,

${ }^{29}$ For a discussion of Rambach see Frei, Eclipse of Biblical Narrative, pp. $38-39$.

30Since Hegel saw himself as continuing the rationalist and positive tradition of the Enlightenment, he would not have recognized that he was asking the reader to supply something that is not present in the history of Spirit. However, the later Schelling's position vis-à-vis Enlightenment theology (and any secularization of it into a spiritual anthropology) is somewhat different, because he applied the pejorative label of 'negative philosophy,' among other things, to developments in post-Renaissance theology such as deism. 
the uneasy marriage between metaphysics and a hermeneutics that inevitably implies the linguisticality of understanding comes close to breaking in later enactments of the hermeneutic project like Kierkegaard's Concept of Irony. But as we shall also see, the result is not to refute categorically the hermeneutic claim that one can proceed beyond the merely semiological to something deeper.

The assumptions of hermeneutics pervade Hegel's work and are not just found, as one might expect, in his Aesthetics. Indeed, The Phenomenology of Mind is a hermeneutics of intellectual history, which develops principles that Hegel will later apply to aesthetic genres and techniques. The most important of these principles is that 'false' or failed forms of awareness are versions of truth and must be reread in a historical perspective. Spirit goes through the three stages of being-in-itself (an sich), then being-for-itself ( $f$ ür sich), and finally being-in-and-for-itself at once. Correspondingly, the Idea is at first undeveloped because it is un-selfconscious, then it becomes fully self-conscious but mental and intentional, and finally it becomes fully elaborated and concretely present in life. The teleological structure of the human project allows us to unfold individual modes of consciousness toward their completion through a divinatory reading. Thus Hegel of ten seems to approach the analysis of a mode of consciousness deconstructively, by showing it as thwarted by its internal discrepancies. But he also suggests that the perspective of history allows us to read aporias into a logic of contradictions. As in typological reading, of which his method seems a secular variant, the relationship between past and present modes of consciousness provides the logic for leading present modes of awareness in the direction of the future. Thus stoicism (in retrospect) prefigures scepticism in the movement toward absolute freedom. Stoics free themselves from the world as it is but imprison themselves in a single attitude: namely, the rejection of life. Sceptics still fail to participate in life but at least exercise freedom in the domain of thought, by refusing to be tied to any single position $(P M$, pp. 244-45). As scepticism is more complete than stoicism, so we can imagine present forms of awareness such as the unhappy consciousness being progressively freed of their contradictions in the advancing spiral of intellectual history. What should be clear is that Hegel's method of reading fissures within a form of consciousness so as to posit their eventual closure derives from the hermeneutic procedure of understanding the part in relation to the whole. He breaks the hermeneutic circle at the level of history and sublates the grammatical reading of the history of ideas as a process riddled with contradictions into a psychological reading of it as a purposive development. Indeed, the adjective 'psychological' is his as well as Schleiermacher's, because Hegel places his semiology 
of history in a psychology of history and defines the latter term as the study of spirit determining itself in itself, as a subject for itself. ${ }^{31}$

In the Aesthetics Hegel provides a historical typology of modes designed to explain the asymmetries between content and execution found in symbolic and romantic art, in such a way that they, too, seem generative rather than deconstructive. Hegel's approach to art is phenomenological and psychological rather than structural: he defines the forms of art as "the different ways of grasping the Idea as content" or "the different relations of meaning and shape" $(A, \mathrm{I}, 75)$. Ideally, art is "the actualizing and unfolding of the beautiful," "the Ideal in its actualization," the embodiment of ideas in a concrete and therefore persuasive form $(A, \mathbf{I}, 299,105)$. The completed work of art is also the selfactualization of the artist as medium of the world-historical spirit: in it one "produces" oneself in an external medium where one enjoys "in the shape of things only an external realization of himself" $(A, \mathrm{I}, 31)$. Hegel thus distinguishes in art two terms, which he variously calls "theme" and "execution," "meaning and shape," "Idea and presentation," or "inwardness and external manifestation" ( $A$, I,96,300,74,301). The perfect work, ontologically speaking, is "the union of meaning with its individual configuration" $(A, \mathrm{I}, 101)$. Psychologically speaking, it is the finding of an adequate outer shape for something inward, so as to bring about "the unity of the artist's subjective activity with his topic and work" $(A, \mathrm{I}, 602)$.

But of the three historically successive modes of art that Hegel analyzes - the symbolic, the classical, and the romantic - only the second achieves this unity of the technical and psychological. Classical art is the "adequate embodiment of the Idea" $(A, \mathrm{I}, 77)$. It is the achievement of an organic form, in which the presence of a form that is indwelling rather than a shape that is superinduced reflects the fact that the Idea has become concrete. But in both symbolic and romantic art meaning is separate from the shape that it tries uneasily to inhabit. Symbolic art, being the product of the earliest phase in the phenomenology of mind, fails to achieve identity with itself because of a deficiency of selfconsciousness. Its content remains indeterminate and its forms "rather a mere search for portrayal than a capacity for true presentation" $(A, \mathrm{I}, 76)$. Sometimes a symbolic work may be overpatterned, in an attempt to determine externally a content that is still vague $(A, \mathrm{I}, 133)$. In romantic art, on the other hand, the Idea is fully developed, but external forms have become inadequate to embody it. Once again, as a consequence, the art form manifests a discrepancy between inner and outer, a failure to

\footnotetext{
${ }^{31}$ Hegel, Encyclopedia of the Philosophical Sciences, trans. William Wallace (Oxford: Clarendon Press, 1971), pt. 3 , sec. $3^{87}$, p. 25.
} 
objectify meaning. A useful gloss on Hegel's triad of aesthetic modes is Schelling's distinction between schematic, symbolic, and allegoric art in The Philosophy of Art. Schematic art uses the general to point to the particular. It has an abstract and formal grasp of the Idea, that has been unable to root this understanding in the concrete world. By contrast, allegoric art uses the particular to point to the general: it conveys a subjectively complete grasp of the Idea, which it is unable to universalize. The middle term alone, symbolic art, is the union of subjective and objective. ${ }^{32}$

Although the Aesthetics is not explicitly a theory of reading, Hegel is concerned to emphasize the aspect of understanding: the fact that art is not an autonomous structure but is created "for a public" $\left(A, \mathrm{I}, 263_{3}-64\right)$. The classical work seems not to require the supplement of interpretation. It "describes itself through itself" and "unfolds itself before our eyes." 33 But for the most part Hegel deals with art forms that lack this clarity. Moreover, he does not just describe the decorums characteristic of a rhetorical criticism that dismisses texts that are not 'classical' and universal. He also engages in the deeper reading of surface failures that characterizes a hermeneutic criticism that tries to grasp even the spirit of imperfect works. For instance, the decorum of epic, in contrast to that of lyric, requires a maximum of detail if clarity is to be achieved. But Hegel is also concerned to understand the historical reasons for techniques in major narrative forms that derealize what is being conveyed. His Aesthetics is thus a phenomenology of art not only in the traditional sense of trying to grasp the spirit behind individual forms, but also in the more contemporary sense of considering forms in terms of their effect on the reader. Among the characteristics of romantic art that have the eff ect of derealizing content is indeterminacy of characterization: the "undisclosedness, . . . absence of outward shape . . . lack of expression and development" that distinguish a character "based in inwardness" $(A, I, 580)$. Such a character can appear as flat and unconvincing $(A, I, 582)$, so that the nexus of thematic concerns associated with it lacks solidity. Also characteristic of this kind of art is a disordering of the events that occur in the objective world: "The spirit has withdrawn into itself out of the externality of appearances which now on their side are shaped no matter how, for they are unconnected with the subject since his inner world no longer sees itself in them" $(A, \mathrm{I}, 586-87)$.

The Aesthetics provides an anatomy, not of criticism, but of aesthetic

\footnotetext{
${ }^{32}$ See Tzvetan Todorov, Theories of the Symbol, trans. Catherine Porter (Ithaca, N.Y.: Cornell University Press, 1982), pp. 208-12. Schelling does not use the word 'symbolic' in the same way as Hegel, but uses it, like Goethe and Coleridge, to indicate the synthesis, not the separation, of the particular and universal.

${ }^{33}$ Quoted in ibid., pp. ${ }^{159-60 .}$
} 
response, and these examples give only the faintest impression of its synoptic aims. Part of this aim is to educate a superreader who will know how to read in the absence of conventional structural codes. For instance, Hegel's descriptions of how romantic art disorganizes the empirical surface by fragmenting character, plot, and setting can well apply to Blake's later prophecies, which present an action that is essentially inward, and leave the "material of the external world ... to go its own way," $(A, \mathrm{I}, 594)$, like an autonomous language whose activities are irrelevant to the true spirit of the narrative. Perhaps more than any other romantic, Blake strains against the limits of the aesthetic, defined as the presenting of "the Idea to immediate perception in a sensuous shape and not in the form of thinking and pure spirituality" $(A, \mathrm{I}, 72)$. The Hegelian method allows us to understand the anti-aesthetic elements in Blake as part of the historical movement of romantic art toward a mode of understanding that it can bring into being only through its own collapse. This method, especially when it is a question of romantic rather than symbolic art, is best described as hermeneutic rather than rhetorical. Occasionally, Hegel will follow the evaluative tendencies of neoclassical criticism and simply judge works of symbolic art as defective, because they fail as acts of persuasion. But the underlying assumption in his presentation of the romantic is that discontinuities between meaning and shape are historically produced, and that the reader committed to grasping the spirit of the work will liberate it from the constraints of formal representation.

Hegel's reading of cultural history leads naturally to a canonical hermeneutics. Texts are read so as to reconceive fissures within them from the higher vantage points of the author's canon, the romantic canon, and finally that project to which Shelley refers as "that great poem, which all poets, like the co-operating thoughts of one great mind, have built up since the beginning of the world" ( $S P P$, p. 493). Such a macrohermeneutics is certainly not new in romantic theory, Friedrich Schlegel's concept of a progressive universal poetry being an example. ${ }^{34}$ But where earlier theorists of ten conceive of the canon as a series of self-contained stages, Hegel's dialectical aesthetics sees each phase as intentionally oriented toward something that it is not, namely, a subsequent phase that may be its antithesis. In assuming a deeper reading that in some ways must negate a grammatical reading, Hegel's work finds itself at a threshold between a positive and a negative hermeneutics. That he nevertheless saw his hermeneutics of cultural history as positive, and that he saw history

\footnotetext{
${ }^{34}$ For an account of Schlegel's hermeneutics see Margaret Higgonet, "Organic Unity and Interpretative Boundaries: Friedrich Schlegel's Theories and Their Application in His Critique of Lessing," Studies in Romanticism 19 (1980): 176, 182, 186.
} 
itself as a rational process unfolding from arche to telos, is clear enough. Indeed, Hegel insists that in symbolic art "the shape and meaning are strange to one another from the start, . . . yet they stand in no negative relation but in a friendly one" $\left(A, \mathrm{I}_{5} 5_{12}\right)$. But whether the Aesthetics consistently enacts a positive hermeneutic is less certain. In speaking of discrepancies between theme and execution, Hegel implies that the positive content of a text is apparent, but that for historical reasons its form is not adequate to its content. The reader's function in the case of a symbolic text is to project the reconciliation of form and content, and in the case of a romantic art form to read through (but not to reverse) the grammar or form to arrive at the real content. But Hegel also suggests that form reflects rather than disguises content, and that "defectiveness of form results from defectiveness of content" $(A, \mathrm{I}, 74)$. If that is the case, he must envisage a supplementary reading that corrects or resists the content, instead of simply discarding the form to unfold the content.

The problem of how complete the meaning is even at the level of conception surfaces in the specific discussions of symbolic and romantic art in terms of 'indeterminacy.' Many of the symbolic forms that Hegel discusses-allegory, parable, didactic poetry-posit a meaning that they simply fail to make concrete. Didactic poetry provides a content "already cut and dried and developed explicitly as meaning in its therefore prosaic form" alongside an artistic form "tacked on . . in an entirely external way" $\left(A, \mathrm{I}, 4^{23}\right)$. Blake's Marriage, which uses the parabolic and didactic forms, may be an example of a symbolic text requiring no more than positive animation from the reader. But, on the other hand, Hegel frequently distinguishes symbolic from romantic art in terms of "indeterminacy": meaning and shape remain separate in symbolic art, because the meaning is "not yet conscious of itself." $35 \mathrm{He}$ also describes the "relation of the Idea to the objective world" as "a negative one" $(A, \mathrm{I}, 77)$ and thereby suggests that a hermeneutics of the symbolic must negate both content and form to arrive at the Idea. Coleridge's Christabel might be an example of a text that is 'correctly' understood only from a vantage point in the future, and only if the indeterminate relationship between Christabel and Geraldine is determined and morally schematized. In the indeterminate text, meaning is not represented in a positive but abstract way; rather, the reader must avoid working through what is in the text and must construct what is not there. Romantic art seems far simpler in that its content is supposedly determinate but purely inward $(A, I, 519)$, and withdrawn from that immersion in corporeality constituted by artistic form and language. Yet there is something troubling about describing as 'positive' a reading that requires one to burn away the language in

${ }^{35}$ Encyclopedia, pt. 3, sec. $5^{61}$, p. 295. 
which the 'meaning' is expressed. Moreover, in Hegel's own terms, the deficient form must express some deficiency in content, and a divinatory reading will once again have to imagine a content that is not there and to repress the aporias in what is there.

This discussion can only touch on some of the more general ways in which Hegel takes the hermeneutic project beyond his predecessors. To begin with, he displaces an organic into a historical model of understanding and translates the synchronic identity between subject and object affirmed by Coleridge and the early Schelling into a constantly deferred identity. The interpretation of spirit is now something that has to occur through difference, process, and displacement. Friedrich Ast had developed from the philosophy of the early Schelling a hermeneutics that was temporal but not historical. The identity of the text was grasped through the equivalent of the subject-object fusion: namely, a reading that identified author and reader. This understanding was not immediate, but it occurred through a sequence of more or less contemporaneous acts. But in Hegel's hermeneutics the art form must be understood by placing it in a context that is still unfolding, and we must project ourselves forward to a point in the literary historical process from which we can re-vision a form that could not fully understand itself at the time of its composition. In other words, Hegelian hermeneutics stands more perilously at the threshold between a meaning that is potentially present and one that is still absent.

For Hegel, then, texts are not just historical in the sense that their original spirit is obscured by time, but also in the sense that their meaning is unfolded and even changed by history. Hegel's introduction of the historical dimension into hermeneutics thus renders problematic the notions both of an original meaning and of a definitive reading. Previously, psychological reading had unlocked the meaning of the text by putting us in contact with the author's voice. But for Hegel there is no author in the sense of an origin. The author is merely the medium through which the conflicting voices of a given historical period speak, and the aporetic texts or systems of thought thus produced can be properly read only as they are unfolded toward their resolution in the historical process. The disappearance of the author is inevitably the disappearance of the implied reader as well. Hegelian hermeneutics, even as it tries to determine the direction of reading, actually leaves much more to the constructive powers of the explicit reader than does traditional hermeneutics. To put it differently, Hegel's methods are constantly at odds with his hermeneutic goal of getting at the truth. Try as he will to salvage an essentialist concept of meaning by using metaphors of inner and outer, soul and body, to separate the Idea from its appearances in the discourse of history, Hegel cannot really disentangle a transcenden- 
tal signified from the process of its signification, which constantly makes and unmakes it. Moreover, his own readings open up interpretive options that his system seeks to foreclose. Even as he assumes a reading that will reconstitute the positive meaning of the art form across its negativity, the readings he provides show how art forms do not cohere. It is not of course to individual readings that one looks for this higher strategy of interpretation, but to their cumulative relationship as a typological series. But the story told in The Phenomenology of Mind, the story of how 'spirit' progressively understands itself as it constitutes itself in successive systems of thought, is not always one of diminishing contradictions. It is not clear, for instance, that the unhappy consciousness is closer to identity with itself than scepticism; indeed, it seems to deepen rather than resolve the problems of the latter. The hermeneutic story told by the Aesthetics is similarly ambiguous. Hegel seems to present the movement from symbolic to romantic art as a development from shadowy types to truth, in which the reading of discontinuous forms becomes progressively easier because romantic art, which has a definite though purely inward content, guarantees that the indeterminacy of symbolic art was always the potential presence of a fixed meaning. In this story, though the need for a psychological reading at odds with the grammatical one persists throughout the history of the cultural text, the requirement ceases to raise problems about the identity of the text. But the opposition between symbolic and romantic art of ten seems a tenuous one. It is just as possible that the Aesthetics tells a different story: one of repeated unreadability rather than increasing readability. Romantic art is haunted by the same problems as a symbolic art: a collapse of meaning at the obvious level that is not clearly accompanied by the reconstitution of a firm meaning at a deeper level. In classical art, where meaning is completely adequate to shape, the need for interpretation is momentarily eliminated, but in romantic art the disappearance of a referent once again becomes a problem.

Both Hegel's Phenomenology and his Aesthetics yield a model of canonical interpretation that incorporates methods from typological reading to create a logic and a logos binding past, present, and future. Such interpretation aims to be a grand expansion of the 'positive' hermeneutics earlier discussed, which sees itself as developing a meaning that is always embryonically present. But, as we have seen, the introduction of the historical dimension renders problematic the presence of determinate meaning. Yet an awareness of this indeterminacy coexists in Hegel with a powerful desire to interpret and direct it. I have used the term 'negative' hermeneutics to indicate a reading that resists the elements of difference and negativity in the text to posit a meaning that is highly speculative. Schelling, too, saw Hegelian phenomenology as 'negative' in the 
sense that it failed to deal with positive facts. ${ }^{36}$ It is also negative in that it fails to deal with language, with what it has itself articulated in language. Despite the fact that dialectic (as Adorno has pointed out) is committed to the linguisticality of understanding, ${ }^{37}$ Hegel's exaltation of the 'romantic' finally signals a rejection of representation. But Schelling's own 'positive' philosophy, to which we shall now turn, is even more negative in finally demanding a leap of faith that bypasses his careful articulation of things as they are. With Schelling, the crisis of a hermeneutics committed to cognitive theism deepens, as does the impossible separation between the 'true' text and the language of events.

Envelopment, Involution, and Irony:

Schelling's Hermeneutics of Negativity

So far, the hermeneutic procedures described share an assumption that the grammatical level of the text intimates the psychological level. Yet if the nineteenth-century emphasis on the supplement of reading is radical in a way that its eighteenth-century precursors in an aesthetics of affect were not, it is because the connection between levels is increasingly disturbed, and the referent becomes more and more a projection of interpretive desire. We spoke earlier of a group of texts that require not simply deepening but reversal if their 'true' meaning is to be unfolded. The incorporation in such texts of 'figures of reading' that encourage a reversal of the text's grammatical meaning can be linked to an important shift in the concept of mimesis, from the imitation of what is there to what is in fact absent. This shift, of course, is not a sudden one. It may have its genesis in the earlier idea of an imitation that improves rather than copies, but it also moves beyond this notion in supposing an 'imitation' that must oppose rather than improve the original. Thus for Jean Paul literature is still the imitation or reflection of something that objectively exists, yet what it imitates is not empirical but hidden. Poetry, he argues, "should neither destroy nor repeat but decipher reality." She "represents that highest life which is eternally lacking in all our reality, even in the most beautiful reality of the heart; she paints the future drama on the curtain of eternity. She is no flat mirror of the present, but

\footnotetext{
${ }^{36}$ See David Punter, Blake, Hegel and Dialectic (Amsterdam: Rodopi, 1982), p. 61. I disagree, however, with his comparison of Schelling's critique of Hegel to that of Marx. The 'positive facts' that Schelling sees Hegel as neglecting are not material but metaphysical facts.

${ }^{37} \mathrm{Cf}$. Theodor Adorno's comment: "Hegelian dialectic was a dialectic without language, while the most literal sense of the word 'dialectic' postulates language": Negative Dialectics, trans. E. B. Ashton (London: Routledge and Kegan Paul, 1973), p. 163.
} 
the magic mirror of the time which is not yet." 38 Even more significantly, Jean Paul sees poetry as a mimesis that can be at odds with what it ostensibly imitates. The copy may contain "more than the original" or even produce "its opposite," because "a double nature is being imitated: an outer and an inner one." 39

Jean Paul is concerned with literature and not with its reading. But it is difficult for the text to conflate the real and the ideal in this way without seeming escapist-a dilemma that of ten bothers Jean Paul, who feels that the "organic synthesis ... between the old realism and the new idealism" may elude him. ${ }^{40}$ Thus in the practice of romantic literature it is of ten not the text that supplements reality, but the reader who must supplement the text of reality through a reading that deciphers rather than repeats, an interpretive copy that contains more than the original. The hermeneutics of reversal, however, is subtended and legitimated by a shift in the sense of what it is that constitutes poetic imitation. That Jean Paul's notion of aesthetic production would even bear the name of imitation is interesting, as we consider the curious survival of metaphors like the mirror in a period that has supposedly discarded a mimetic in favor of an expressive aesthetics. It suggests the continued importance of the norm of representation, as a source of anxiety about any aesthetic or hermeneutic that is not mimetic, because it defers the presence of meaning from the text to some medium like authorial consciousness or reader response that lacks the tangible materiality of the former.

As already indicated, the metaphysical underpinning for a hermeneutics of reversal can be found in the later work of Schelling. Schelling's philosophy went through several phases. He himself distinguished two: an initial phase encompassing the Naturphilosophie and the System of Transcendental Idealism (1800), and a later phase that he characterized as his 'positive' philosophy-somewhat puzzlingly, given its proto-existential awareness of contingency and its historical position as a bridge between Hegel and Kierkegaard. From the early 'philosophy of identity,' which seems to resolve the subject-object dialectic that is temporalized and deferred in the later philosophy, Friedrich Ast actually developed a hermeneutics of identity. The famous concept of the hermeneutic circle describes three stages in the reading process that parallel three similar stages in the spiral of the creative process itself: from an uncritical presentiment of the work's unity, we move through a grammatical analysis of its parts that of ten seems inimical to a grasp of its wholeness, to a critical understanding of its totality informed by a knowledge of its particu-

${ }^{38}$ Jean Paul, Horn of Oberon: Jean-Paul Richter's School for Aesthetics, trans. Margaret R. Hale (Detroit: Wayne State University Press, 1973), p. 309.

39Ibid., p. 24.

${ }^{40}$ Ibid., p. 306. 
larity. ${ }^{41}$ It is arguable that Ast ignores those buried complexities in the philosophy that the later Schelling himself could not so easily put aside. The positive philosophy attempts to remedy what Schelling saw as the twofold deficiency of Hegel's and his own earlier philosophy. On the one hand, Schelling, like Kierkegaard, felt that Hegel's phenomenology failed to be positive: Hegelian dialectic was essentially negative, and without its "terminus ad quem" in the utopia of Absolute Spirit, "Hegelian being would remain unfulfilled as what it is, namely, nothing." 42 The positive philosophy, by contrast, would reveal the presence of being within existence rather than simply deferring it. On the other hand, the shortcoming of what Schelling called the negative philosophy was paradoxically that it did not take sufficient account of the negative momentum within existence: of the primacy of lack and nonbeing, and of the irrational ground of things. Idealism, defined as the denial of the primordial negating power, is to be eschewed. Schelling's later work thus involves two important recognitions: that the Hegelian attempt to posit a presence behind the signs of history actually turns out to be negative in that it does not succeed in actualizing anything, and that any future hermeneutic must ground itself in those obstacles to positive activity that Hegel reveals but does not recognize. As such, it initiates both an increased awareness of the crisis of representation in romanticism, and a deepening of that crisis. For Schelling deconstructs hermeneutics as it exists in his time: he recognizes that romantic philosophy has not succeeded in communicating the presence of a positive referent, despite strategies of deferral which allow this referent to be conveyed on other than a grammatical level. And yet he intends to ground his own positive philosophy on a conscious embrace of precisely those things that had turned Hegel's philosophy into a negative hermeneutic.

To speak of Schelling's philosophy as a hermeneutic and to extrapolate from it methods of reading literary texts is not as much of an imaginative leap as it may seem, given his frequent references to God as an artist and his use of literary terms like 'irony' to characterize this artistry. ${ }^{43}$ It is not so much that Schelling sees the same productive activity at work in nature and art, as had been the case in the System of Transcendental Idealism. Rather, the history of consciousness-whether of metaphysics, of art, or of myth-is a series of signs, a book that calls for

\footnotetext{
${ }^{41}$ On Ast see Rudolph Makkreel, Dilthey: Philosopher of the Human Studies (Princeton, N.J.: Princeton University Press, 1975), p. 268.

${ }^{42}$ Quoted in Karl Lowith, From Hegel to Nietzsche: The Revolution in Nineteenth-Century Thought (New York: Doubleday/Anchor, 1967), p. 114. For Kierkegaard's similar criticism of Hegel, see $C U P$, p. 34 n.

${ }^{43}$ See $A W$, pp. 71, 77, 168. See also George Seidel, Activity and Ground: Fichte, Schelling, and Hegel (New York: Georg Olms, 1976), pp. 123-24.
} 
interpretation, but not in the conventional sense of a liber naturae that already contains the meanings to be decoded, because it also calls for reading, for a productive and applicative understanding that will unfold what is only potentially in it. Indeed, Schelling signals the fundamentally hermeneutic nature of his project in The Ages of the World by introducing the unfinished account of the ages with the inquiry into the nature of understanding already discussed. But the text itself goes far beyond any hermeneutic outlined in its introduction. Schelling apparently conceived of three ages in the history of consciousness: past, present, and future, and wrote the introduction as an approach to understanding the first of these through "recollection" or retelling. The understanding of the future as what is "divined" rather than what is "known" will necessarily proceed on very different principles $(A W$, p. 83$)$. We might expect from the introduction that the extant text will be a fragment, the first part of a three-part project. In fact, as F. de Wolfe Bolman indicates, it is more or less complete $(A W$, p. $68 \mathrm{n}$.): a collapsed philosophic epic, a recollection of the past as seen from the present in such a way that it points toward the future. The principles outlined for the understanding of the past by itself are thus too limited to represent adequately what Schelling actually does in combining the archeological hermeneutics of recollection with the teleological hermeneutics of divination.

The Ages is an attempt to understand being, to discover its arche and telos $(A W$, p. 93). But it begins with the premise that what confronts us as we look at the past is the absence of being, the very negation of what the interpreter seeks. Briefly, Schelling argues that the ground of the positive must be sought in negativity and unfolded through a dialectic of reversal. Such reversal is possible because everything contains the seed of its opposite, so that negation contains a hidden root of positivity $(A W$, p. 208): "only an inversion, a turning out of what is hidden and a turning in of what is manifest, is needed in order to transplant and transform, as it were, the one into the other" $(A W$, p. 114). That something is absent does not mean that it does not exist, for nonbeing is the ground of coming-to-be: the "power of negation displaces, we said, the will of love and that of the spirit, yet only from the present. It posits these wills as not being, yet in no way therefore as nonbeing, but as future, and, as such, to be sure, also as being (only concealedly)" ( $A W$, p. 205).

Much of Schelling's text is concerned with the theological problem of a deus absconditus. But his discussion bears on the linguistic problem of whether there is a transcendental signified, because his approach to the disappearance of God is essentially hermeneutic. The Ages is about how to read the signs of creation correctly, so as to go beyond their manifest content by substituting a psychological for a grammatical reading. Like Schleiermacher, Schelling uses the term "divination" to describe such a 
reading, but he also requires us to make an imaginative leap from the grammatical to the psychological in order to see nonbeing as the dialectical ground of being. The concept of absence as a deferred presence explains the absence of "external revelation" $(A W$, pp. 205-6) in literature as the consequence of a temporary problem in the semiotics of history and requires us to unfold the true meaning of a narrative by reversing it. Crucial to Schelling's hermeneutics of nonbeing are the notions of envelopment, involution, and irony. "Envelopment" describes the transitional state in which God appears to have withdrawn from the world, because the positive power has been hidden inside the negative power $(A W$, p. 205). "Involution" similarly describes a state of being turned inside out ( $A W$, pp. 205-6). The assumption that a positive meaning is enveloped within a negative one allows Schelling to propose an almost mathematically neat formula: "the negating power is the only manifest aspect of God; the real essence, however, is the hidden aspect. The whole therefore stands as $\mathrm{A}$, which, outwardly, is $\mathrm{B}$ " $(A W, \mathrm{p} .110)$. The systematic counterreading of textual signs is summed up in the principle of irony, which Schelling uses to describe the text of creation as an inverted world produced under conditions where there is a gap between essence and existence. In this inverted world, God himself "disguises himself and appears to be another, and in consequence of this divine art of dissimulation or irony displays the reverse of that which he genuinely wills." 44 Schelling's description of divine irony applies equally to the ontology of the text, which similarly requires antithetical reading if the work within it is to be unfolded.

Schelling himself links the envelopment of a positive within a negative revelation to the typological reading of the Bible $(A W$, pp. 158-62). But there is a significant difference. Fixing on the shadowy tokens of hope in order to unseal the envelope of a disastrous narrative is partly justified in the case of the Bible by the fact that the New Testament exists. The Ages, like the romantic texts and canons of which it is representative, does not contain its own future. It relies, somewhat circularly, on the biblical parallel in order to place the ironic moment within a secular scripture that, if it existed, would justify the placing of irony within it. But the dilemma posed by what the romantics very broadly called irony is not so easily resolved. The increasing concern with this mode can be explained by seeing it as a focus for a cluster of anxieties regarding the disappearance of a referent. For irony at its most basic puts in question the existence of literature as a positive activity, that is, as an activity that posits something. In theory, Schelling provides a model for producing something positive from the ironic text. In practice, given that the re- 
reading of irony requires a supplementary critical act, this model has the effect of a double negation. On the one hand, it allows readers the freedom to imagine something other than things as they are and thus negates empirical reality by making us feel that it must be the sign of something beyond it. On the other hand, any alternate state of affairs envisioned by the reader is negated by the fact that it is not yet real.

\section{The Text of Absence: Kierkegaard's Concept of Irony}

In The Concept of Irony Kierkegaard elaborates in textual terms the hermeneutics of the negative developed by Schelling. But he also explores the problems minimized by the latter's assumption that the process of reversal, once begun, can be arrested, and that the psychological meaning is somehow less figurative than the grammatical meaning. For Kierkegaard's essay does not really provide a method that can be abstracted from the process by which it is developed. Unlike Hegel's work, it does not attempt a metacritical stance, irony being its mode as well as its subject. Rather, it reenacts the strategies of earlier hermeneutics so as to demonstrate their continued hold on the imagination, but also so as to push them to an extreme where they disclose themselves as figures of reading. Written fairly late in the hermeneutic tradition, The Concept of Irony both deconstructs that tradition and continues it on the level of desire. Through the figure of Socrates and (implicitly) Jesus, it explores those margins of the hermeneutic enterprise approached by Schleiermacher, where the psychological meaning vanishes, because the person being studied is known only through testimony of disciples. It also brings out more clearly the problems of interpreting the unsaid by placing itas Hegel and Schelling do-in a larger context so as to def er the positing of meaning to the future.

The Concept of Irony is concerned with a unique problem: the interpretation of meaning where none is posited, or the reading of what one might call the silent text. Where the text as Schelling conceives it says the opposite of what it means, the text that interests Kierkegaard is one that is constantly vanishing. For the central figure in Kierkegaard's discussion is Socrates, who committed nothing to writing or speech and presents himself as an absence: "He was not like a philosopher lecturing upon his views, wherein the very lecture itself constitutes the presence of the Idea" $\left(C I\right.$, p. $\left.5^{\mathrm{o}}\right)$. Rather, Socrates' method being irony, whatever is said is simultaneously unsaid. With the extension of methods from literary interpretation to the reading of persons, and particularly to someone like Socrates, we have reached the ultimate challenge to the hermeneutic tradition. The possibility that the representation of meaning may be 
unnecessary for reading to occur has been raised explicitly. At the same time the hermeneutic recuperation of meaning from within its derealization has been pushed to a limit where it comes to seem absurd, in the philosophic sense of that word.

Within the spectrum of tropes used by the romantics to crystalise some relationship between appearance and reality, and hence between the surface and depth of the text, irony stands at the opposite pole from the symbol. Symbol is defined by Solger as "the presence of the Idea itself in existence." Translated from metaphysical into literary terms, it becomes the mode of the fully actualized text, in which the complete unity of inner and outer form makes it unnecessary to search for a hidden meaning:

in the true symbol the external object has merged itself with the light of the inward essence, and is entirely one with it, so that this inner light is not to be found by itself in a particular part, nor even in the inner core of the thing, but equally over its entire external surface; and one could well say that it is the task of the artist to turn the inwardness of things into their outwardness. ${ }^{45}$

Irony and its cognates, however, provide only "disintegrating external forms" that must be given a deeper interpretation if they are to yield anything meaningful. Humor turns "everything to nothing, including the idea," though it can be seen more profoundly as "the sublime turned upside-down, or a finite applied to the infinite." More positively, wit is a "spark that leaps suddenly over intermediate steps" but that, because of the way it functions, consumes what it suggests. Finally, irony itself may be the negation of a positive truth (as it is in Schelling), or more commonly, the suspension of any truth whatever. ${ }^{46}$ On the face of it, what Kierkegaard attempts is a hermeneutics of irony, the philosophic standpoint that Hegel had dismissed because of its "infinite, absolute negativity" $(A, \mathrm{I}, 68)$, and around which cluster romantic anxieties about texts that derealize themselves. This attempt to reconceive in a positive way a mode that threatens to deny altogether the positive power of language is not without precedent. Hegel to the contrary, Friedrich Schlegel sees the decreative power of irony as consistent with the teleological project of a progressive universal poetry and finally connects irony (particularly Socratic irony) with love. Indeed, as Marshall Brown points out, romantic irony is of ten linked to allegory and hence to the abstract positing of

\footnotetext{
${ }^{45}$ Karl Solger, Erwin, or Four Dialogues on Beauty and Art, in Kathleen Wheeler, ed., German Aesthetic and Literary Criticism: The Romantic Ironists and Goethe (Cambridge: Cambridge University Press, 1984), p. 130.

46Ibid., p. 128.
} 
meaning. If irony and allegory both disjoin appearances "from the world of significance, with only the secondary difference that allegory points toward the higher meaning and irony does not," ironic destruction and allegoric anticipation are frequently coupled together, ${ }^{47}$ so as to yield an idealism that is dialectical and critical rather than dogmatic.

Amidst these attempts at idealization, what is remarkable about Kierkegaard's essay is that he does not elide the deconstructive potential of irony by perceiving it as creative and fertile. 48 Unlike Solger, Kierkegaard is not interested in wit and humor, nor does his concept of irony (like Schlegel's) include these modes in all but name. Within the triad of ironic forms that Solger studies, wit and humor display a certain positive energy that colors his understanding of the third term, irony. But Kierkegaard, in contrast, emphasizes the negativity of irony, seemingly in order to argue that though it is everything Hegel says it is, it is still consistent with the assumption of wholeness in the individual's history. Beginning his account of irony with Socrates, he focuses on the enigmatic nullity of the Socratic personality which, as we strip away the attempts by Plato and Xenophon to give it a positive identity, turns out to be an "empty space," a "nothingness" $\left(C I\right.$, p. $\left.5^{6}\right)$. Some of the problems explored by Kierkegaard had already been raised by Schleiermacher in his essay on Socrates: the enigma of a philosopher who is not present in his discourse, the difficulty of trying to know him through the contradictory accounts of Plato and Xenophon, the difficulty of disentangling 'Socrates' from 'Plato,' and indeed the question of whether there is a real Socrates. ${ }^{49}$ These problems in turn suggest various problems in literary hermeneutics. They include the difficulty of grasping truth when there are different versions of it, and also the question of how to find the true voice of the author behind the figurative voices that represent and displace it in subsequent critical traditions. It is an indication of Kierkegaard's difference from the philological positivism of earlier classical study that he cannot rest with Schleiermacher's view that Socrates created something, namely, the dialectical method. As Kierkegaard attempts to disentangle the Socratic from the Platonic voice in the dia-

${ }^{47}$ The Shape of German Romanticism (Ithaca, N.Y.: Cornell University Press, 1979), pp. 99100.

48I refer to Anne Mellor's discussion of romantic irony, which she identifies with Schlegel. Mellor emphasizes the unstable though fertile character of irony, without giving sufficient attention to the continued transcendental element in it: English Romantic Irony (Cambridge, Mass. : Harvard University Press, 1980), pp. 3-25. Another recent discussion of nineteenth-century theories of irony is Lillian Furst's Fictions of Romantic Irony (Cambridge, Mass.: Harvard University Press, 1984), pp. 23-48.

${ }^{49}$ Schleiermacher, "The Worth of Socrates as a Philosopher," in The Apology of Socrates, The Crito and Part of the Phaedo, with notes from Stallbaum, Schleiermacher etc. (London: Taylor Walton and Maberley, 1852), pp. cliv, clii. 
logues, Socrates' contribution turns out to be the evacuation of originary meaning, where the attempt to fill this ideological void through systematic philosophy and myth is Plato's addition. There are according to Kierkegaard two kinds of questions, of which only the second is authentically Socratic: "One may ask a question for the purpose of obtaining an answer ... or ... to suck out the apparent content with a question and leave only an emptiness remaining" (CI, p. 73$)$. Similarly, there are two kinds of dialogue: the "constructive dialogues which are distinguished by an objective and systematic presentation" and which are essentially Platonic, and the ironic dialogues, in which alone the truly Socratic emerges in the form of a refusal to use language to construct meaning (CI, p. 9o).

This may not sound like promising ground for a phenomenological rather than poststructuralist concept of irony. Indeed, Kierkegaard seems to have deconstructed the hermeneutic project, by following the classic strategies of traditional hermeneutics only to parody them. For he goes from a grammatical reading of the texts in which Socrates is represented (the dialogues), to a more psychological and inward reading of the person himself, only to disclose Socrates' personality as an absence. This is not the end, however. For Kierkegaard then goes on to reverse his deconstruction and to reconstruct the identity of the Socratic 'text' from its apparent nonidentity. The seeming nothingness of Socrates becomes, in turn, a surface that invites further reading, and this deeper psychological reading, of Socrates and of the irony that is his modus vivendi, reveals that absence is the representation of a still unarticulated presence. Kierkegaard then introduces his famous gloss on the Hegelian definition of irony, a gloss that seems to create a transcendental signified from its very disappearance, and to refute Hegel by placing the Socratic moment within the larger context of the history of Spirit: irony "is negativity because it only negates; it is infinite because it negates not this or that phenomenon; and it is absolute because it negates by virtue of a higher which is not" (CI, p. 278). Kierkegaard does not believe in a world-historical spirit or in the rational unfolding of history, and would feel that Hegel emphasizes the collective spirit at the expense of the individual. Nevertheless, there is something Hegelian about this suggestion that the present is the ground of the future, and that the signs of the present must be given not just a literal or even a psychological reading, but also a divinatory reading. The conclusion, furthermore, draws on some of the most orthodox strategies of Christian hermeneutics. It seems to elide the problem posed by romantic irony, by seeing it as a false type of Socratic irony, and it further seems to reorient the negativity of the latter, by seeing Socrates as a type of Jesus, who similarly confronts the interpreter with a textual silence that is not an absence. 
The parallel between Socrates and Jesus, earlier drawn by Hamann, ${ }^{50}$ allows Kierkegaard to make the ironic mode a type-though not an equivalent - of the prophetic mode:

For the ironic subject the given actuality has completely lost its validity; it has become for him an imperfect form which everywhere constrains. He does not possess the new, however, he only knows the present does not correspond to the Idea.... [he] is in one sense prophetic, to be sure, for he constantly points to something future; but what it is he knows not. While he is prophetic in this sense, his position and situation are nevertheless the opposite of the prophetic. (CI, p. 278)

Kierkegaard's essay could be seen as providing, through a phenomenology of the ironic spirit, a model that allows for the reading of the apparently unreadable text. The canonical readings of Blake which reinterpret the ironic stance of Urizen by making it prefigure the prophetic stance of Jerusalem employ such a model, perhaps without any awareness of Kierkegaard. But throughout this discussion I have used the word 'seems' because it is not at all clear whether Kierkegaard is providing or playing with hermeneutic models. For one thing, the strategies of reading he uses repeat those he criticizes in others. For example, his argument that irony can be counterread into something positive depends on a binary opposition between a 'true' Socratic irony, which is the prelude to something positive, and the 'false' romantic irony of Schlegel and Tieck, which continually negates. But Kierkegaard himself undermines this opposition. For instance, his description of Socratic irony as "hovering" uses language reminiscent of Schlegel (CI, p. 279). And in his discussion of Socrates and Plato he is unable to see Platonic positivity as the fulfilment of Socratic negativity, dismisses it as a mere supplement, and thus raises the question of why any future positivity should be any less supplementary. In undoing the opposition between Socratic and romantic irony, he thus veers toward the 'romantic' position that defines irony as infinite (but not absolute) negativity. Second, Kierkegaard's negative hermeneutic, which he developed as a way of grappling with complexities ignored by post-Enlightenment thinkers like Schleiermacher and Hegel (at least as the nineteenth century saw them), involves a series of readings rather like Chinese boxes. It radically destabilizes the process of reading by making it potentially endless. It is, to be sure, a dialectical hermeneutics, but that is not to say the dialectic is progressive. For if we move from reading the representation of Socrates in the dialogues to a more inward reading of Socrates as a person, only

50J. C. O'Flaherty, Hamann's Socratic Memorabilia: A Translation and Commentary (Baltimore: The Johns Hopkins University Press, 1967). 
to find that this inward reading of him as phenomenologically absent is again an outer shell that conceals something potentially more positive, who is to say that this new 'inner' meaning is not a further representation that fails to get at the truth? We are not quite prepared for this textual vertigo when we read Kierkegaard's definition of irony as a figure in which the word is in opposition to its true meaning, and the reader simply negates the word to arrive at this meaning $(C I, \mathrm{p} .265)$. The trope of irony allows the reader, through a hermeneutics of reversal, to posit what the text does not. The mode of irony, however, is more complicated. In Kierkegaard's own enactment of a negative hermeneutic, which considers irony as a modus vivendi rather than in the more limited form of a trope, the process of supplementing the text through the act of reading seems to turn back on itself, and reading ceases to be a positive activity.

In the end it is difficult to say whether the essay on irony dismantles the hermeneutic project or continues Schelling's endeavor and shows it triumphing over incredible odds. Kierkegaard's essay is the first of the works considered in this chapter to present itself as text and not simply theory, although other works may in practice function this way. Our reading of it will depend on whether we give priority to the theological or aesthetic side of his work, to what he says or to how he says it. Pierre Macherey suggests that one think of a text as "exhibiting" rather than expressing an ideology, as repeating ideology so as to display its gaps and become "the mythology of its own myths." 51 This view of the text as "criticism," as the displacement of ideology, is very different from and more subtle than the work to which Barthes refers as "ideological criticism and semiological dismantling." 52 Semiological dismantling analyzes a text or a tradition of ideas in such a way as to uncover the gaps that expose it as a product of false consciousness. But a critique generated by repetition rather than explicit deconstruction allows mythology to display its gaps by letting it speak and thus also display itself. Kierkegaard exhibits the strategies of traditional hermeneutics in such a way as to defamiliarize them as textual strategies. But emptied out, they become available for repossession by the reader as strategies with which we can play. Perhaps Kierkegaard himself provides the best description of how the simultaneous affirmation and unsettling of an idea functions, when he points out in the Concluding Unscientific Postscript that "to write a book and revoke it is something else than not writing it at all" (CUP, p. 548). He provides another useful gloss on this procedure of ambiguously

${ }^{51} A$ Theory of Literary Production, trans. Geoffrey Wall (London: Routledge and Kegan Paul, 1978), p. 6o.

52Roland Barthes, Image, Music, Text, trans. Stephen Heath (New York: Hill and Wang, 1977), p. 166. 
dismantling and reproducing an ideology in his term "dialectical reduplication," which involves a translation of a truth intellectually apprehended into the terms of actual living ( $P V$, pp. 16-18, 166). A text can be seen as the dialectical reduplication of a theory, a repetition that simultaneously enacts it and throws it into relief, translates the theoretical into the real and the proper into the figurative.

The dialectical reduplication of a system of ideas is in a sense its deconstruction. Yet Kierkegaard's use of deconstruction differs considerably from what recent theory has accustomed us to, in reinscribing everything that it criticizes. The unique method of The Concept of Irony may seem less puzzling if we remember that Derrida distinguishes between two forms of deconstruction. The more common form, used by Nietzsche, involves a decision "to change terrain, in a discontinuous and irruptive fashion, by brutally placing oneself outside, and by affirming an absolute break and difference." But there is also a form of deconstruction that attempts "an exit . . . without changing terrain, by repeating what is implicit in the founding concepts and the original problematic, by using against the edifice the instruments or stones available in the house." Derrida is concerned with the tendency of both modes to reinstate the habits of thinking they attack. A deconstruction based on ironic repetition "risks ceaselessly confirming, consolidating, relifting" what it deconstructs, whereas one based on rupture inverts the oppositions it exposes, "thereby inhabiting more naively and more strictly than ever the inside [it] declares [it] has deserted." 53 But Kierkegaard's avoidance of rupture needs to be seen as deliberate and productive rather than dangerous. For the fact that he is no less committed to placing existing categories of thought under erasure than a more ruptural thinker like Nietzsche and yet will not openly break with the hermeneutic tradition is surely one of the most significant things in the rhetoric of that tradition's attempt to read itself. In the next chapter we will explore the ambiguities of the Kierkegaardian deconstruction, as well as the revisionary hermeneutics that emerges from his work and, less vertiginously, from that of Schleiermacher.

${ }^{53}$ Jacques Derrida, Margins of Philosophy, trans. Alan Bass (Chicago: University of Chicago Press, 1982), p. 135. 